\title{
Subsurface Structural Investigation for Evaluation of Hydrocarbon Potential Using Aeromagnetic Data over Parts of Southeastern Nigeria
}

\author{
Nwokeabia, Charity Nkiru ${ }^{1}$, Ibe, Kalu Kalu², Ibeneme, Sabinus Ikechukwu³ , Orji, Chikwendu Emenike ${ }^{4}$, Adikwu, \\ Stephen Onum ${ }^{5}$, Iduma Uche ${ }^{6}$ \\ ${ }^{1}$ Department of Applied Geophysics, Nnamdi Azikwe University Awka, Nigeria \\ ${ }^{2,3,4,5}$ Department of Geology, Federal University of Technology Owerri, Nigeria \\ ${ }^{6}$ Kelma Geodynamic Limited Abuja, Nigeria
}

\begin{abstract}
Airborne magnetic dataset Studies were carried out in parts of South eastern Nigeria. Airborne magnetic data covering the study area was acquired, processed, and interpreted with the aim of determining the depth to basement of for hydrocarbon potential in the study area. Various data enhancement techniques such as reduction to equator, Analytica Signal, First Vertical Derivative (FVD), upward continuation and 3D euler deconvolution were carried out on the magnetic data in order to filter unwanted signals. Analysis such as sediment thickness was evaluated using the Extended Euler Depth solution. Sediment thickness within the southern Benue Trough ranges from 151.1 to $1297.4 \mathrm{~m}$. Afikpo Basin has sediment thickness ranging from 513.9 to $>3469.6 \mathrm{~m}$, while Anambra Basin has sediment thickness ranging from 228.4 to $>3469.6 \mathrm{~m}$. the thickest sedimentary unit within the Afikpo Basin is geographically located around Bende, Iduma, Ohafia, Okigwe, Abiriba, Uzuakolo and Amaeke, while that of the Anambra Basin is geographically located around Aka Ihobe, Orumba, OwereEzukala, Mbala, Agwu, Isuochi, Akwa, Umuawulu, Ezeagu, Onuba, Agbani and AbawaOgugu. Niger Delta Basin has the high sediment thickness with range of 3469.6 to $6760 \mathrm{~m}$, with the thickest sediment geographically located around Omodema, Abara, Omoecheigbo, Etche, Imogwa, Okoroagu.
\end{abstract}

Key words: Airborne Magnetic, Enhancement technique, sediment, South eastern Nigeria.

\section{INTRODUCTION}

A eromagnetic survey is one of the most frequently used type airborne geophysical survey and has been recognized as a principal mapping tool for materials that are strongly magnetized (Murphy, 2007). The essence of the magnetic survey is to investigate subsurface geology on the basis of the anomalies in the earth's magnetic field resulting from the magnetic properties of the underlying rocks. The physical principle of aeromagnetic method is based on taking the ambient magnetic susceptibility of the subsurface geology and using the data to determine the distribution of the magnetic minerals and hence changes in the lithology (Telford et al., 1990). The susceptibility (magnetic content) is dependent on the type of rock and its environment (Mariita, 2013). Soil magnetic susceptibility can be related to different terrain topography attributes such as the slope, elevation and concavity - convexity of the surface terrain to explain the distribution of magnetic minerals within soil (Appiah, 2015).

The aim is to interpret the study area using high resolution aeromagnetic data in order to estimate the sedimentary thickness of the study area.

\subsection{Location of the Study Area}

The study area lies between longitudes $7^{\circ} 00^{\prime} \mathrm{E}$ and $8^{\circ} 300^{\prime} \mathrm{E}$ and latitudes $5^{\circ} 00^{\prime} \mathrm{N}$ and $6^{\circ} 30^{\prime} \mathrm{N}$ (Figure 1). It extends from Enugu in the north to Uyo in the south and Orsu and Ikot Ekpene communities in the east and west respectively covering a total area of about $27,225 \mathrm{~km}^{2}$. The major towns within the area are Abakaliki, Nkalagu and Afikpo in Ebonyi State, Enugu and Udi in Enugu State, Ugep and Odukpani in Cross River State, Ikot Effang and Uyo in Akwa Ibom State, Umuahia and Aba in Abia State, Oru and Okigwe in Imo State and Chokoche and Abara in Rivers State.

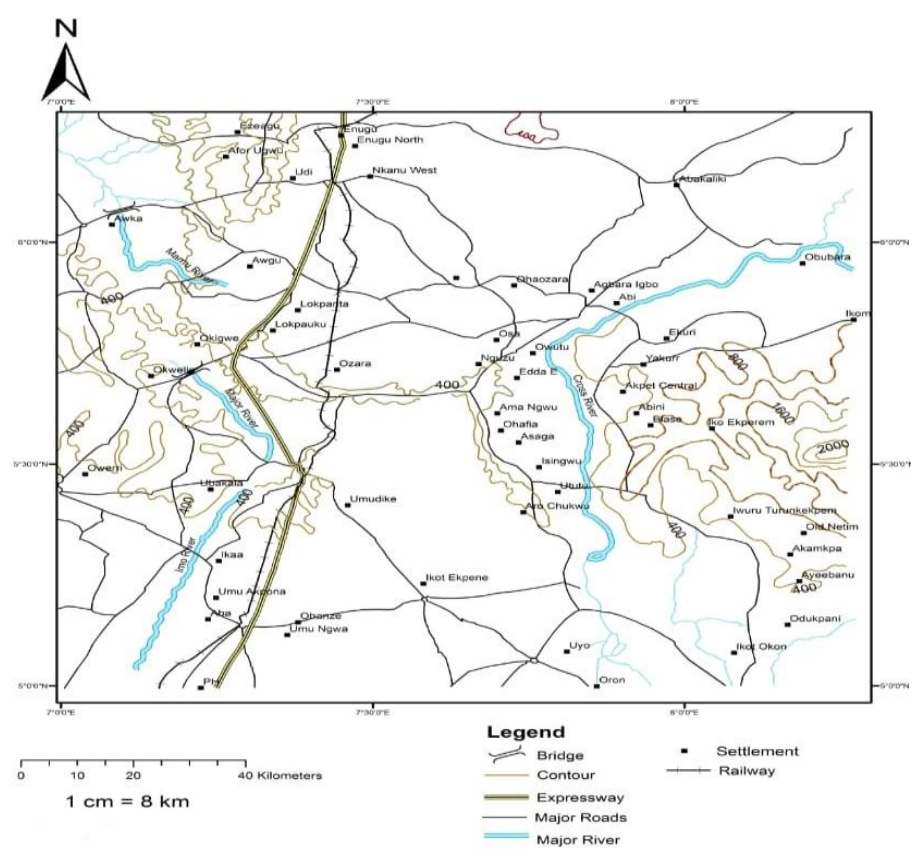

Figure 1: Location /Topographic Map of Study Area 


\section{LITERATURE REVIEW}

The aeromagnetic study revealed that structures trend majority in the NNW, NW and ENE with intersections indicating locations of magnetic intrusions and alkaline ring complexes. The depth source showed an average depth of $4.0 \mathrm{~km}$ for deeper source and 0.45 to $0.7 \mathrm{~km}$ for shallow source. Salem et al., (2000) analyzed aeromagnetic data over Quseir Area Northern Red Sea Egypt using spectral analysis method in order to the relationship between the magnetic anomalies and the geothermal system. Ndougsa - Mbargat et al., (2012) carried out aeromagnetic interpretation over South - East Cameroom to locate buried faults using 3-D Euler deconvolution, analytic signal technique etc. to identify the trends in the magnetic anomaly. The result showed that the depth sources ranged from $600 \mathrm{~m}$ to $6000 \mathrm{~m}$. the structure trend in NW SE direction with a depth of $3000 \mathrm{~m}$ to $4000 \mathrm{~m}$ in the southeast while on the other hand a network of parallel major fault were observed having a shallow depth of $1500 \mathrm{~m}$ trending in ENE - WSW direction. The major fault in the area was interpreted to the associated with the Eburnean orogeny.

\subsection{Geologic setting of Southeastern Nigeria}

The southeastern Nigerian Cretaceous sedimentary basins comprise of the Lower Benue Trough, Anambra and Afikpo Sub-basins, Calabar Flank and Mamfe Embayment. The major controls on sedimentation in the Lower Benue Trough resulted from worldwide eustatic changes in sea level, basin tectonics, and local diastrophism (Odigi, 2012). The earliest sediments in the Benue Trough were Aptian - Albian pyroclastics (Uzuakpunwa, 1974) in the southern portion. These formed the basal unit of the Albian-Cenomanian depositional sequence and were overlain by $2000-3000 \mathrm{~m}$ of sediments of the Asu River Group (Odigi, 2012). Marine sedimentation in the Benue Trough is thought to have begun in Mid-Albian times with deposition of the Asu River Group.

The Asu River Group consists of sequences of shales, limestones and sandstones. The Cenomanian regression
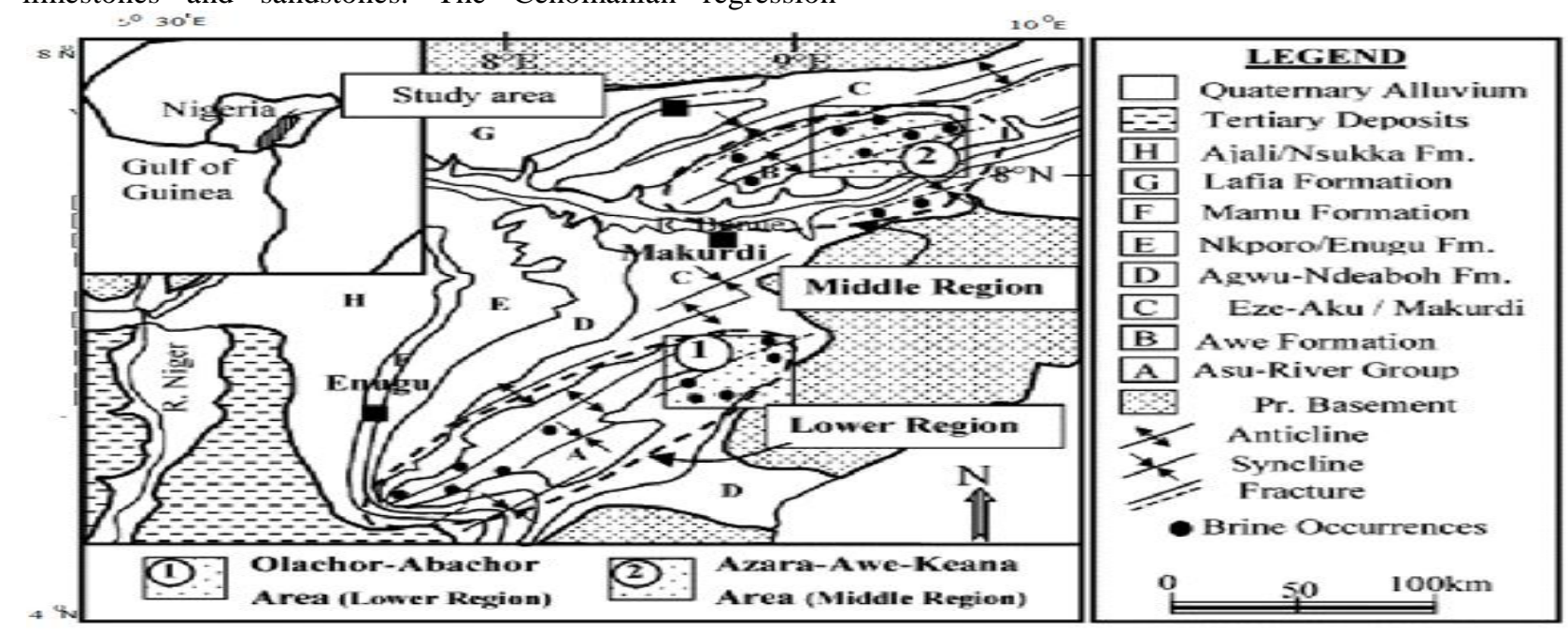

Figure 2.1: General geology of southern portion of Benue Trough (Modified after Olade, 1975) restricted marine sedimentation to the southeastern- most section of the trough. The Odukpani Formation (sequence of sandstones, limestones and shales) and calcareous sandstones were deposited unconformably on the basement rocks in the Calabar Flank during the Late Albian. (Odigi, 2012). The most extensive marine transgressions in the trough occurred during the Turonian-Coniacian times. This led to the deposition of the Eze-Aku Group, comprising of paralic sequences of two marine transgresssive cycles the Late Cenomanian-EarlyTuronian and Late Turonian and Early Coniacian strata unconformably overlying the Middle AlbianEarly Cenomanian Asu River Group (Odigi, 2009).

The Late Turonian-Coniacian calcareous sandstone ridges of storm origin belong to the Amasiri, while the underlying paralic sequences are predominantly shales which grade into bioclastic limestones and sandstones and are referred to as Ezillo Formation (Ojoh, 1992). The Santonian folding and erosion of the pre-Santonian sequences produced postSantonian sediments including conglomerates. The deformation was characterized by horizontal stresses which produced parallel to sub-parallel folds that had northeastsouthwest trend (Nwachukwu, 1972; Olade, 1975). These new structural depressions became depocenters for the formation of the Cretaceous pro-Niger Delta and Early modern Tertiary Niger Delta complex. Overlying the pre-Santonian strata are the Campano-Maastrichtian pro-Niger Delta sediments which were deposited in the Anambra and Afikpo Sub- Basins. The Campano-Maastrichtian beds comprise of conglomerates, sandstones, siltstones and shales. Maximum burial of the Cretaceous sediments probably occurred in the Late Paleocene or Early Eocene during which the Campano-Maastrichtian beds were deformed by terminal Cretaceous tectonism (Odigi and Amajor, 2009). The Campanian- Maastrichtian sediments constitute the pro-Niger Delta and represent the third and terminal Cretaceous marine depositional cycle in the basins (Odigi, 2009). 


\section{MATERIALS AND METHODS}

The aeromagnetic data for this study was obtained from Nigerian Geological Survey Agency. The geomagnetic gradient was removed from the data using the International Geomagnetic Reference Field (IGRF).

The data was further processed, enhanced and interpreted with Geosoft (Oasis Montaj), Arc GIS, and Global mapper. Firstly, on a Geosoft platform the two datasets were projected to Universal Transverse Mercator (UTM) coordinate system Zone $30 \mathrm{~N}$ using World Geodetic System (WGS) 84 as the datum. The data was then gridded with the minimum curvature method of gridding.

The Extended Euler algorithm used is based on the paper by This approach calculates solutions using both the conventional Euler equation and the rotational constraint equation from extended Euler. Solving both equations jointly (extended Euler) gives distance, depth, dip, and susceptibility, assuming there is no remanent magnetization (Reid et al., 1990; Mushayandebvu et al.,2001).

\section{RESULT AND DISCUSSIONS}

The Total Magnetic Intensity (TMI) is the magnetic field that is observed in a particular location, it is a combination of the Earth's magnetic field and the field produced by magnetic bodies located at the subsurface of the study area. Figure 4.1 is the Total Magnetic Intensity (TMI) map of the study area.

The TMI shows the effects of the underlying basement as well as effects of near surface structures within the study area. In the TMI map, areas coloured blue indicate low magnetic intensity, green indicates intermediate magnetic intensity, and red-pink areas indicate high magnetic intensity. The total intensity map therefore shows a very complex pattern of magnetic anomalies. In all the study area the anomalies have a regional gradient with an increasing field intensity from southwest to northeast, with values ranging from -72.3 to $172.5 \mathrm{nT}$. The study area is characterised by low magnetic amplitude ranging from -72.3to $13.3 \mathrm{nT}$, intermediate magnetic amplitude ranging from 13.4 to $85.3 \mathrm{nT}$, and high magnetic amplitude with ranging $>85.3 \mathrm{nT}$. The magnetic variations within the study area trend majorly in the northeast southwest direction with long wavelength bodies occurring within the central, northern, western and southern parts of the study area, these areas correspond to the sedimentary basins (Southern Benue Trough, Anambra Basin and Southern Niger Delta Basin). The eastern part of the study area is occupied by short wavelength (high frequency) magnetic bodies, it is indicative of magnetic bodies at shallow depth, this area corresponds to the Southeastern Basement Complex around Ugep, Obubra, AgoiIbani, Biase, Ikot Ekpere and Esuk Akpai.

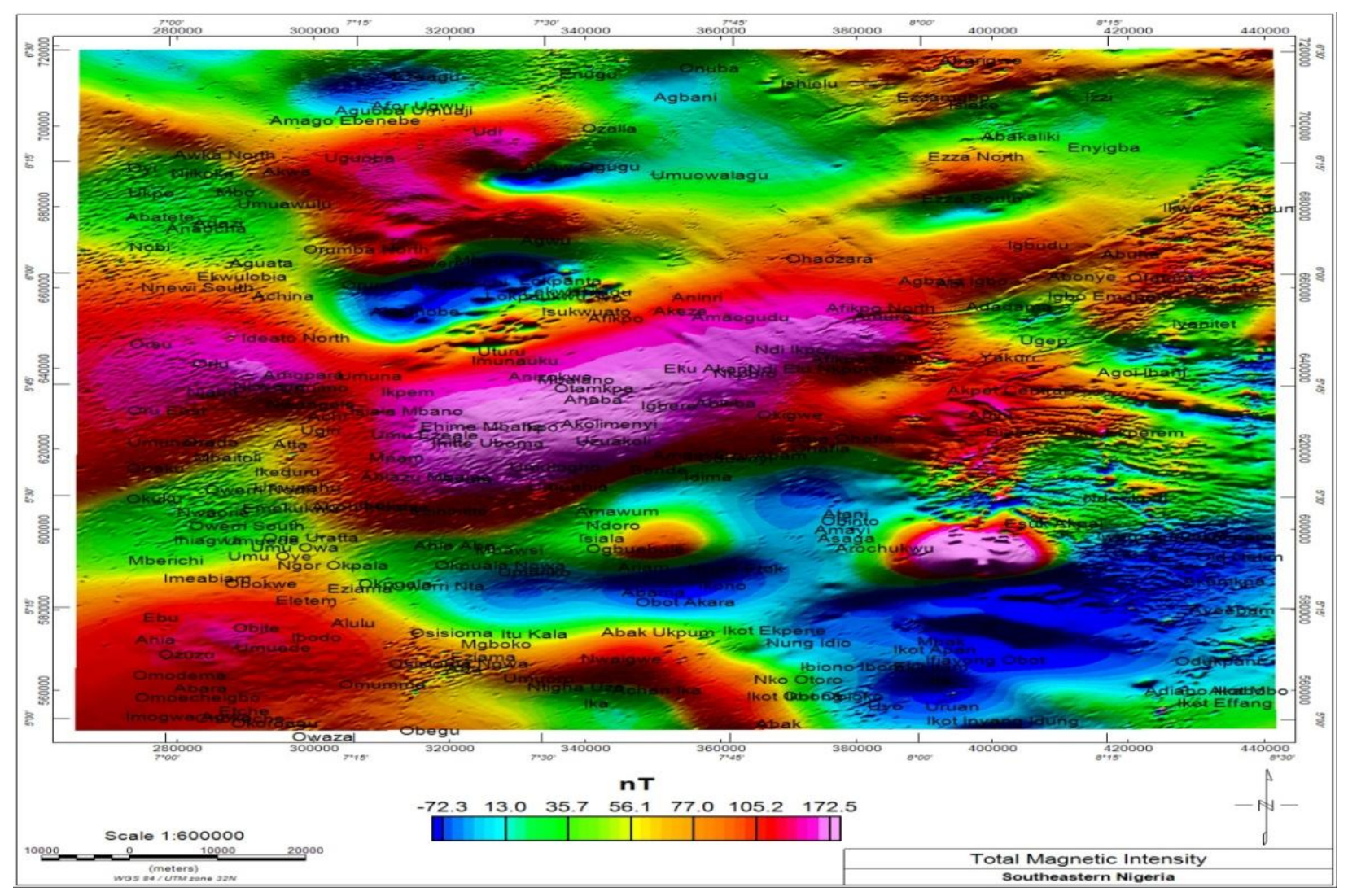




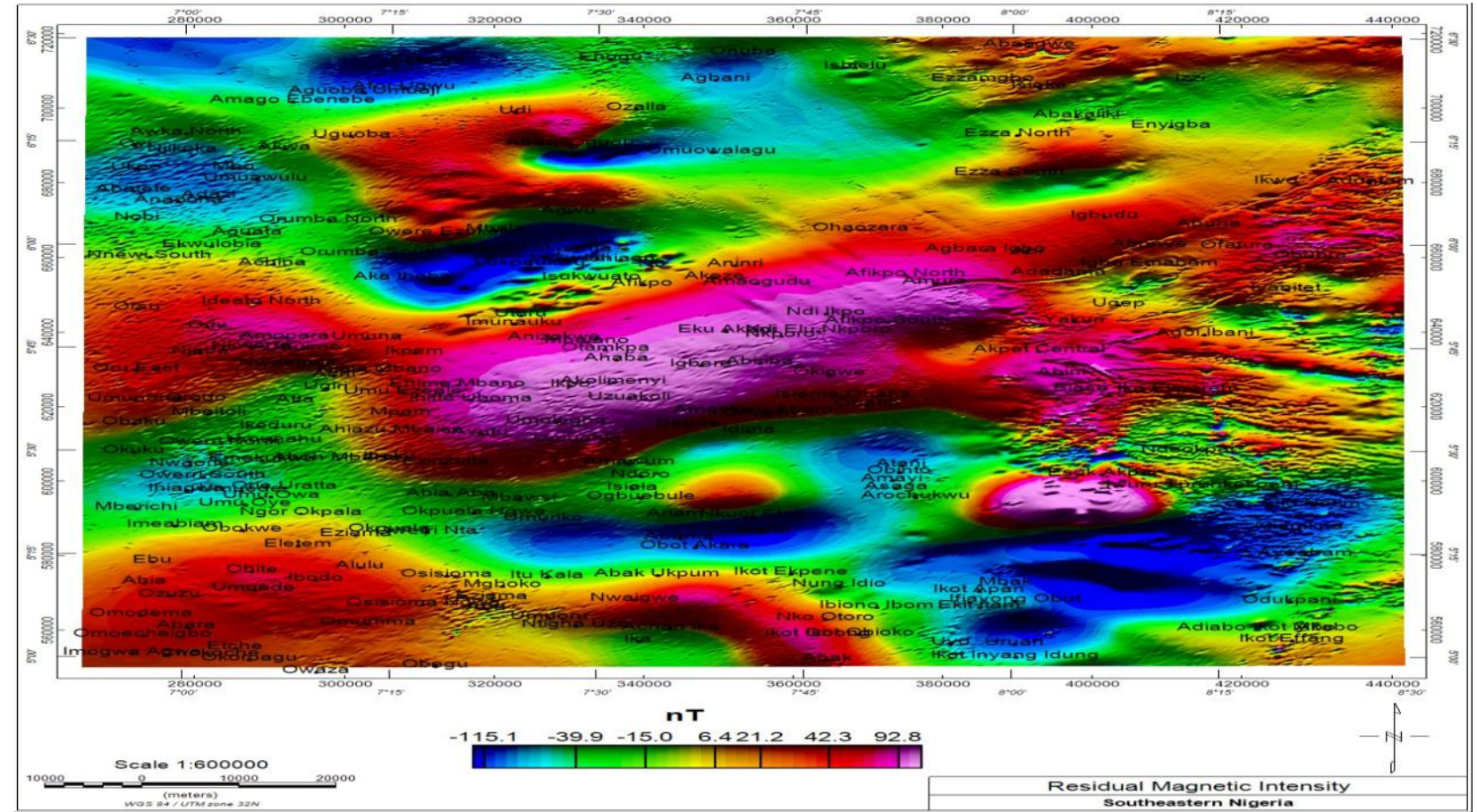

Figure 4.2: Residual Magnetic Intensity map of the Study Area

The first vertical derivative map (figure 4.3), reveals a cluster of dipolar magnetic structure all over the eastern part of the study area, this area interpreted as the southeastern Basement complex of Nigeria, is characterized by rocks such as granite gneiss, biotite granite, porphyritic granite, schist and granodiorites, these rocks are known to be highly faulted and fractured resulting in the almost linear structures observed in the first vertical derivative map. The structures trend majorly in the NW - SE, and EW direction with minor NE - SW directions. Three major folds (FD4, FD5 and FD6) with an average length of about $43.2 \mathrm{Km}$ is observed at the southeastern part of the study area, extending from Odukpani through Ayeebam, Akamkpa, Old Netim to Ndeokpa. The fold is interpreted to have resulted from the second phase of the Santonian event that deformed the Southern Benue Trough.

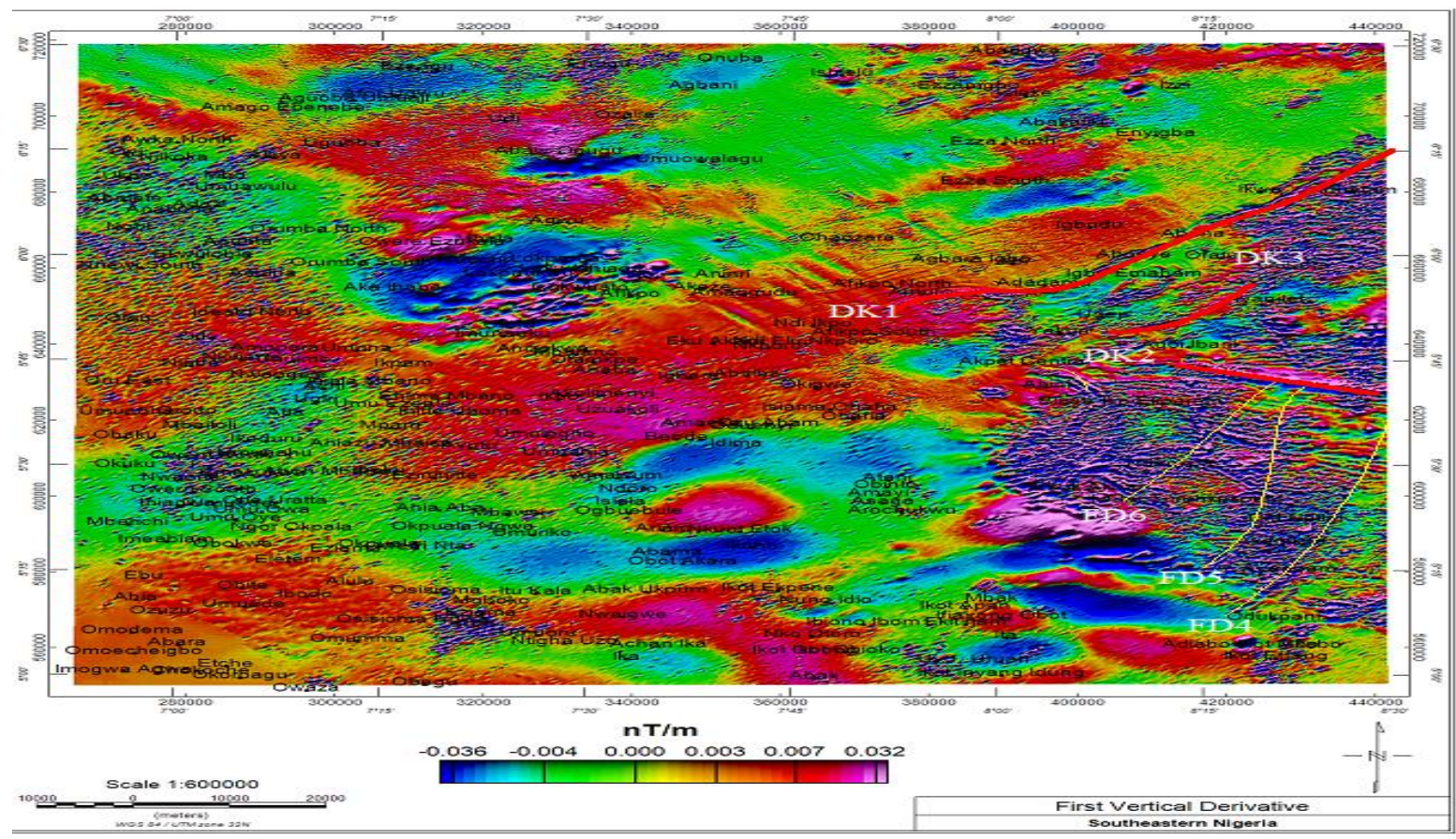

Figure 4.3: First Vertical Derivative Map of the Study Area 
Abakaliki, Enyigba, Ezza North and South, Ezzamgbo, Ishielu, Abauwgu and Izzi area has small weak magnetic signatures with high occurance of dipolar structures accumulated around, Ezzamgbo, Ishielu and Abauwgu area. The structures have a major NE - SW trend. These bodies are interpreted as the diorite rock currently being quarried around Ezzamgbo, Ishielu and Abauwgu area. A high intensity of structures occurs around Enugu, Onuba, Agbani, Udi, and AbawOgugu area, the structures trend majorly NE - SW, with a major fold with axial plane trending westward, stretches from Ozalla to Agbani extending for about $14.9 \mathrm{Km}$. This area is interpreted as the boundary between Abakaliki Anticlinorium (Southern Benue Trough) and the Anambra Basin. Lesser structural occurrence is observed within Ezeagu, Aguoba, AforUgwu, AmagoEbenebe, Uguoba and Awka North, the structures also trend NE - SW, the area is interpreted to fall within the Anambra Basin, with AforUgwu, Aguoba area having weak magnetic signature which indicates probable high depth to basement.

At the central part of the study area, around Lokpaukwu, Ishiagu, Isukwuato, Afikpo, Uturu and Imunauku area shows high intensity of structures trending $\mathrm{NE}-\mathrm{SW}$, this area is notably characterized by low magnetic structures. The high structural occurrence indicates good traps for this fluid, expecially around Isukwuato, Ishiagu and Lokpanta axis. Geologically, these areas (Lokpaukwu, Ishiagu, Isukwuato, Afikpo, Uturu and Imunauku) are also interpreted to be the eastern boundary between the Southern Benue Trough and Afikpo Basin.
Numerous NE - SW trending structures are enhanced in the first vertical derivative maps, around the western part of the study area. The area includes Awka, Ukpe, Mbo, Adazi, Nobi, Orumba North and South, Achina, Nnewi, Orsu, Orlu, AmoparaUmuna, Ikpem, Oru, Atta, Mbano, Mpan, Mbaisa, Ikeduru, Obaku, Okuku, Owerria and Umuahia. The structures within these areas are interpreted to have formed during the breaking of Gondwana supercontinent and the opening up of the southern Atlantic and Indian Oceans in the Jurassic which led to a sinistral strike-slip displacement inherited from preexisting transcurrent fault zones in the Pan African mobile belt then forming the Benue Trough.

The area around Omodema, Abara, Omoecheigbo, Etche, Imogwa, Okoroagu all at the southwestern part of the study area, reflect clear signature with no notable structural deformation, the area is interpreted to geologically fall within the Niger Delta Basin which has no notable tectonic event post basin formation. The structural displacement in other part of the Niger Delta Basin geographically around Ikot Ekpene, Nungdio, Abak, Ika, Nwaigwe, Itu ala, Achan, Ngwa, Eziama, Osisioma, Omumma, Owerri, Alulu, Obite, Umuede, Ibodo, Obite, ObotAkara, Ogbuebule, Ndoro, Ahia, Aba, Okpuala, Ngwa, Mberichi all show displacement in form of dipolar magnetic structures, these were interpreted to have resulted from the tectonic activities occurring within the Benue Trough.

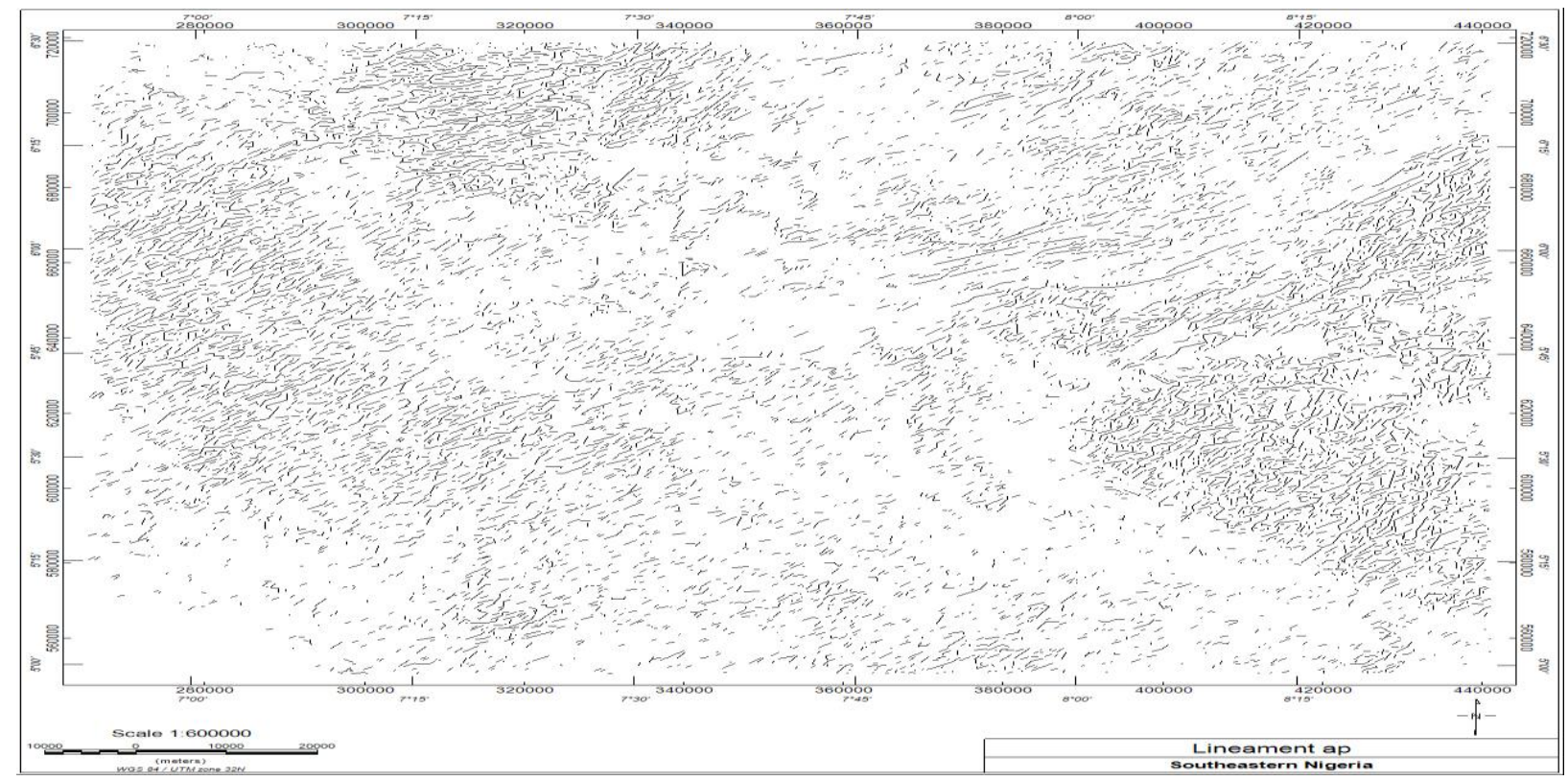

Figure 4.4: Lineament Map of the Study Area

Lineament extraction was done using Center for Exploration Targeting (CET) grid analysis which is a set of algorithms that enhances, locates and vectorizes discontinuity structures within the potential field data. Lineaments maps (Figure 4.4) are linear features which express the underlying geological structures in an area, these lineaments result from faults, joints, folds, contacts or other geological reasons, found in igneous, sedimentary and metamorphic rocks. The lineaments (faults/fractures) are marked in black ticks while dykes and sills are marked in arched curves. The orientation and length 
of the lineament extracted from the lineament map were displayed in a rose diagram to analyze the spatial distribution of lineaments. The rose diagram (Figure 4.5) shows trends majorly in the NE-SW, EW with minor NW-SE, N-S directions. From the extracted lineaments, those at Ugep, Obubra, Adu, Agoibani, Barase, Iko Ekperem, and Esuk Akpai geologically representing the Basement Complex within the study area, trends in the NW-SE direction with minority striking in the EW and NE-SW direction.

The structures within the sedimentary basin trend majorly in the NE-SW with minor NW-SE and NS trends.

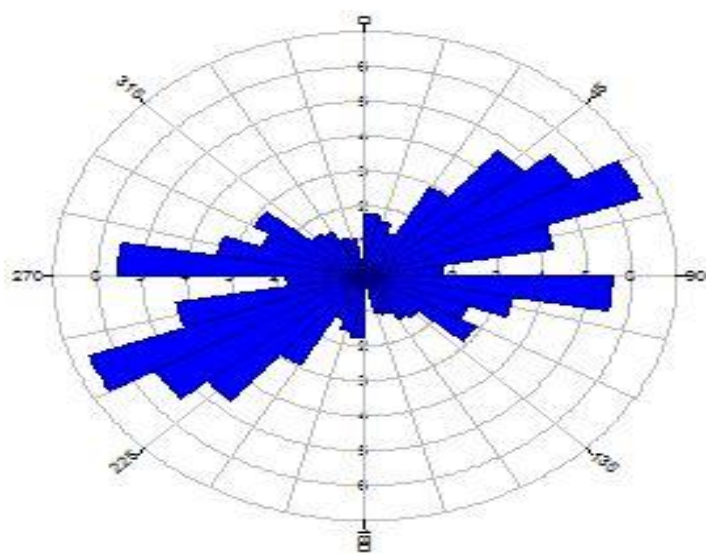

The intensity of deformation within the study area was evaluated using the lineament density map (Figure 4.6). The orientation of the structures within the basin is also evaluated. Areas that have high lineament density indicates high deformation and closeness of the basement rocks to the earth surface, while areas with less lineament density indicates low deformation with plane grounds mainly composed of sediments. Interpreted lineament density indicates intense deformation at the eastern part of the study area, which represent the intense deformation of the Southeastern Basement Complex. The western part of the study area, around is moderately deformed while the area around Enugu, Udi, Agwu, Uguoba, Amego, Ebenebe, Ozalla, Ezeagu and Aguoba show high deformation, this deformation resulted from the uplift of the Abakaliki Anticlinorium. The Southern Benue Trough shows moderate to low deformation but the centre of the Abakaliki Anticlinorium shows higher deformation around Abakaliki, Ezza North and South, Izzi, Enyigba, Abarigwe, Ohaozara and Ezzamgbo. The map also shows that Osisoma, Eziama, Aba and Ngwa areas are highly deformed due to plutonic rock mapped, around Arochukwu, Asaga, EsukAkpani area shows low deformation. Lokpanta, Isukwuato, Ishiagu and Uturu reflect moderate deformation owing to the occurrence of intrusive rocks within the area.

Figure 4.5: Rose Diagram of the Study Area

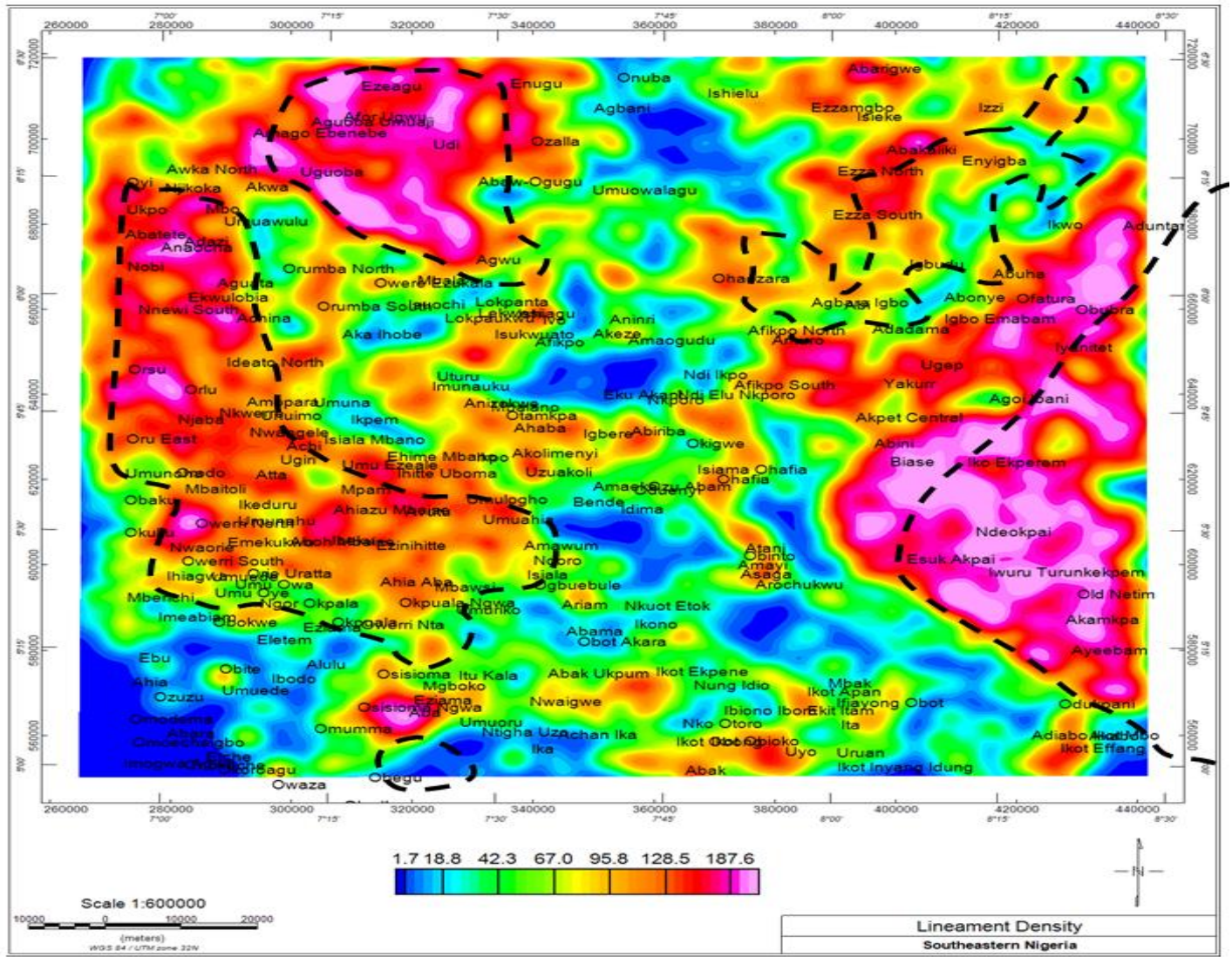

Figure 4.6: Lineament Density Map within the Study Area. 
Three structural cycles were interpreted from the regional geology, structural orientation and cross cutting relationships. The early structural cycle is related to the opening of the Benue Trough, it formed two fault systems trending NE - SW as interpreted around the western part of the study area, at Awka, Ukpe, Mbo, Adazi, Nobi, Orumba North and South, Achina, Nnewi, Orsu, Orlu, AmoparaUmuna, Ikpem, Oru, Atta, Mbano, Mpan, Mbaisa, Ikeduru, Obaku, Okuku, Owerria and Umuahia, and NW - SE faults as interpreted around Ndilkpo, Afikpo North, Aninri, Amaogudu, Agbara.

The second structural cycle is characterised by compressional movement that resulted in the three folds observed at Aka Ihube, Orumba South, Uturu for the first fold, the second at Agwu, AbawOgugu and Umuowalagu, the third at Ozalla to Agbani. This cycle resulted in the formation of the Abaklaiki Anticlinorium and the Afikpo Syncline, it also formed the structures observed around Abakaliki, Enyigba, Ezzamgbo, Ezza North and South, Ishielu and Abangwa which are known to be mineralized.

The third structural cycles is characterised by subsidence which resulted in the formation of a delta around Omodema, Abera, Omoecheigbo, Etche, mogwe and Okoroagu at the southwestern part of the study area. The subsidence is characterised by non-structural deformation within the area and deformation at the boundary indicates possible uplift.

The interpreted structural history is in agreement with Murat (1972), who identified three major structural cycles in southeastern Nigeria. These are: (a) The Aptian - Early Santonian, related to the initial rifting of the southern Nigerian continental region and opening of the Benue Trough. This phase produced two principal sets of faults trending NE - SW and NW - SE. The NE - SW set of faults bound the Benue Trough while the NW - SE deformed the Calabar Flank. (b) The Turonian - Santonian, which was characterised by compressional movements resulting in the folding of the Abakiliki Anticlinorium and the complimentary Afikpo Syncline with emplacement of Lead-Zinc mineralization within the trough. (c) The Late Campanian - Middle Miocene phase produced rapid subsidence and uplift in alternation with subsequent progradation of a delta.

\subsection{Depth to Magnetic Basement}

To compute the depth, five profiles (figures 4.7, 4.8, 4.9, 4.10 and 4.11), were taken cutting across the basins in the area.

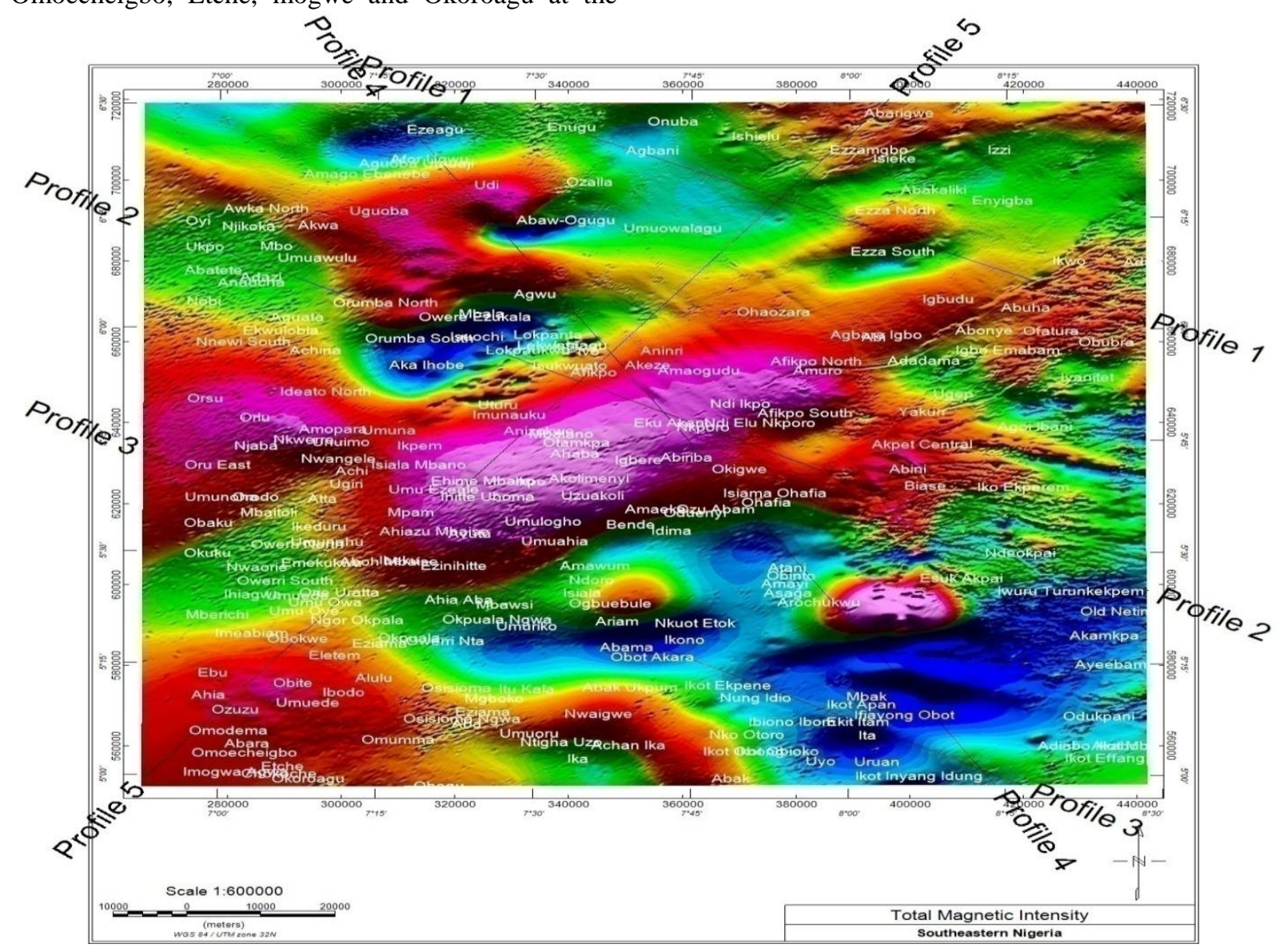

Figure 4.7 Interpreted Profile Lines on the Total Magnetic Intensity Map

Profile one (figure 4.8) trends NW SE and runs from Enugu to Obubra. The depth to shallow magnetic sources around Enugu and Agbani area ranges from -100 to $200 \mathrm{~mm}$ while deeper sources at depth between 1000 to $2100 \mathrm{~m}$, the near surface 
structure could have resulted from thick ferruginized sandstone bodies. The highest depth across the profile is around Umuowalagu with shallow sources ranging from 200 to $500 \mathrm{~m}$ and deeper sources ranging from 3000 to $4500 \mathrm{~m}$. Ezza North and South, Abakaliki, Enyigba and Ikwo recorded 100 to $700 \mathrm{~m}$ for shallow magnetic sources and 1500 to 2000 $\mathrm{m}$ for deeper magnetic bodies. The shallow depth to basement is around Obubra, Abuha and Ofatura, with depth to deepest point ranging from 500 to $800 \mathrm{~m}$.
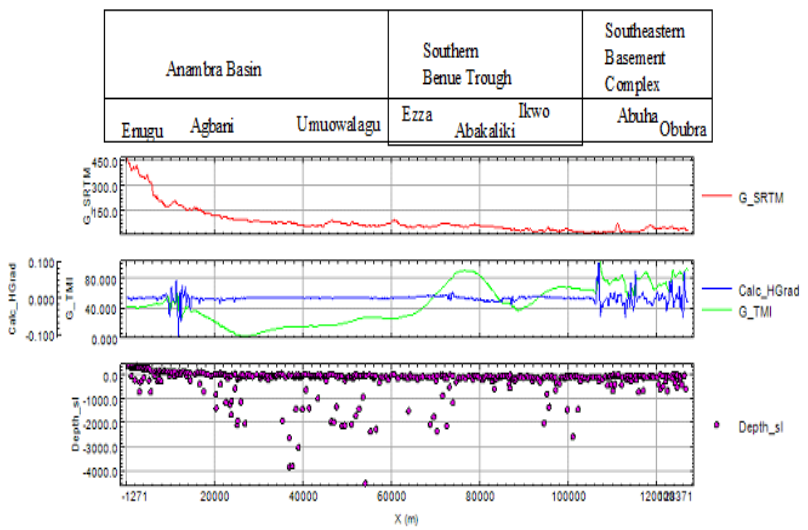

Figure 4.8: Profile One

Profile two (4.9) also trends NW SE and runs from Oyi to Turunkekpem. The depth to shallow magnetic sources around Oyi, Ukpo, Abatet, Mbo, Umuawalu, AnaochaAguata, and Orumba ranges from -20 to $400 \mathrm{~m}$ which the deeper bodies ranges from 800 to $2100 \mathrm{~m}$. Aka Ihobe, Owere, Orumba South, Mbala and Isuochi area recorded depth to basement ranging from 2000 to $4200 \mathrm{~m}$ and shallow magnetic bodies at depth of about 100 to $1000 \mathrm{~m}$. Isukwuato, Uturu, Lokpaukwu, Lokpanta and Ishiagu has shallow magnetic basement depth range of 0 to $500 \mathrm{~m}$. Afikpo, Eze Akan, Okigwe, Abiriba, Ohafia and Nkporo area has depth to basement ranging from 4000 to $5000 \mathrm{~m}$ for it deepest part and 50 to $2000 \mathrm{~m}$ for its shallow depth magnetic bodies. Abini, Biase, Ndeoppai, EsukAkpai and Turunkekpem has the shallowest depth to basement across the profile, with depth ranging from 0 to $1500 \mathrm{~m}$ at it deepest point.

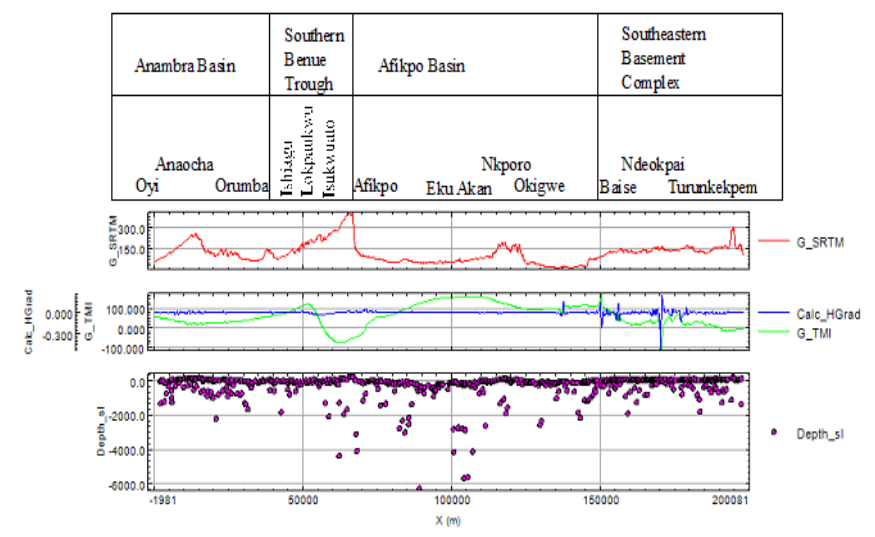

Figure 4.9 Profile Two

Profile three (4.10) extends from Oru West to Ikot Inyang. The depth to basement around Oru West, Umuno, Mbaitoli, Atta, Ikeduru, Owerri, Mbeisa, Ezinihitte ranges from 2500 to $5500 \mathrm{~m}$ with shallower basement depth range of 800 to $2000 \mathrm{~m}$, shallower depth observed across the profile result from ferruginization of thick sandstone bodies. Mbawsi, Ngwa, Umuriko, Ariam, Abama, ObotoAkara and Ikot Ekpene has depth to basement ranging from 2000 to $4000 \mathrm{~m}$. There is a shallow basement region separating the high basement depth (thick sedimentary cover) at Mbawsi, Ngwa, Umuriko, Ariam, Abama and ObotoAkara (Niger Delta Basin) from Mbak, Ikot Apan, Ita, Uruan, Ibiono Ibom and Ikot Inyang, its located between Ikot Ekpene and ObotAkara, it has a basement depth of $<1000$ m. Ikot Ekpene, NungIdio, Mbak, Ikot Apan, Ita, Uruan, Ibiono Ibom and Ikot Inyang has a basement depth ranging from 2000 to $5000 \mathrm{~m}$.
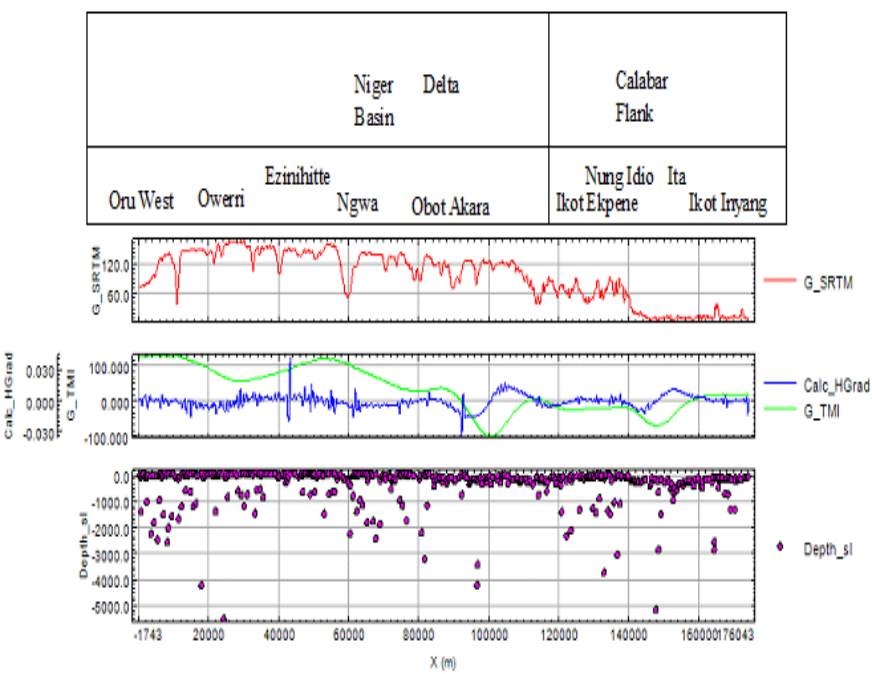

Figure 4.10 Profile Three

Profile four (figure 4.11) stretches from Ezeagu to Ikot Inyang. From northwest to south east, Ezeagu, AforUgwu, Udi, AbawOgugu and Agwu has depth to basement ranging from 2000 to about $3200 \mathrm{~m}$, with the deepest point around Ezeagu. Lokpanta, Ishiagu and Ivo area has depth to magnetic basement range of 500 to $1000 \mathrm{~m}$. Akaeze, Afikpo, Eku Akan, Nkporo, Okigwe and Ohafia recorded depth to basement of 2000 to $6000 \mathrm{~m}$ with the deepest point around Afikpo, Akaeze axis and the depth around Okigwe and Ohafia ranging from 2000 to $2700 \mathrm{~m}$. The profile cuts across the plutonic rock around Arochukwu, Asaga area, it has a depth of burial of about $1000 \mathrm{~m}$. Mbak, IfiayongObot and Ikot Inyang show depth to basement ranging from 2500 to $6100 \mathrm{~m}$, with the deepest point east of Mbak. 


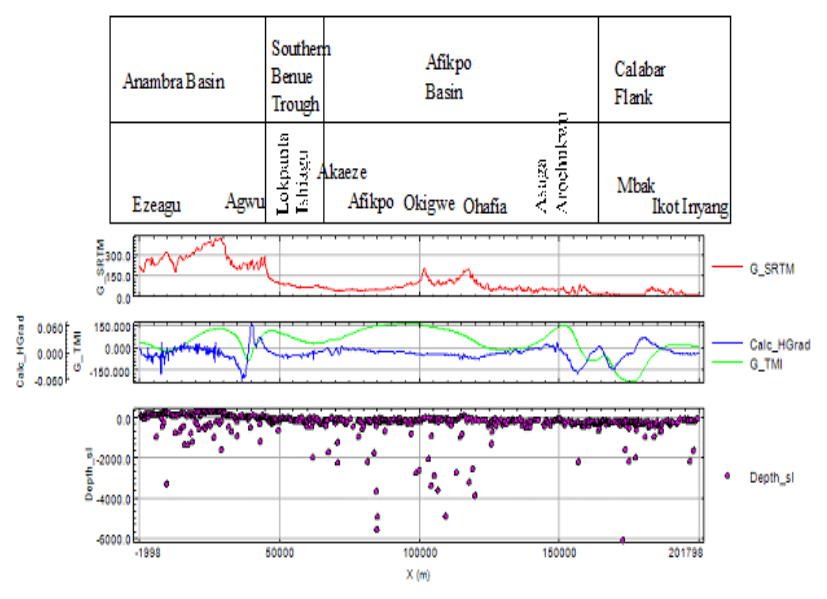

Figure 4.11 Profile Four

Profile five (4.12) cuts across the study area, from the southwest to the northeast of it. The profile stretches from Omoecheigbo at the southwestern part of the study area to Abarigwe at the northeastern part of the study area. Omoecheigbo, Ozuzu, Ahia, Ebu, Obite and Obokwe has depth to magnetic basement ranging from 2500 to $3700 \mathrm{~m}$. NgorOkpala, UmuOwa, Uratta, Aboh, Mbiese and Ahiazu Mbiese has depth to basement of about 1000 to $2200 \mathrm{~m}$. Mpam, Ihitte, Ezeale, Ehime, Uboma, Anizokwe, Otemkpa, Imunauku, Afikpo, Akaeze and Aninri has depth of 2000 to $4800 \mathrm{~m}$, with the deepest areas located between Ehime and Anizokwe, and around Afikpo. Ezzamgbo, Isieke, and Abarigwe area has depth ranging from 700 to $1500 \mathrm{~m}$.

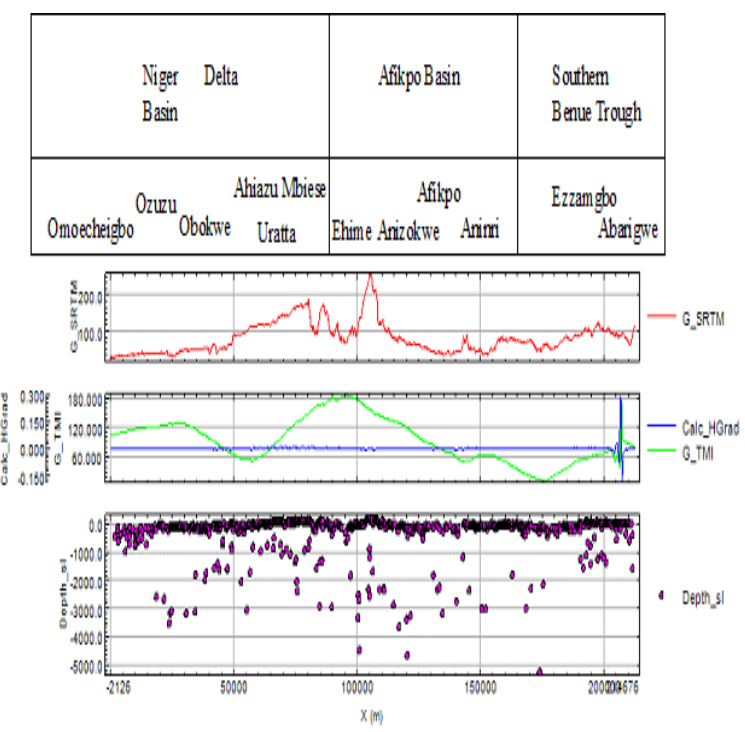

Figure 4.12: Profile Five

The shallower magnetic sources recorded within the study area may be as a result of activities in the basement complex of southeastern Nigeria and activities of the santonian orogeny. These tectonic activities account for the complex regional fracturing within the study area. Magnetic lineament map shows major fault trending NE-SW direction with minor fault trending NW-SE and N-S direction. These trends are in conformity with the structures of the Niger Delta Basin, Anambra Basin - Afikpo Basin and Southern Benue Trough (Nwagide, 2009) and could serve as a migratory pathway for hydrocarbon or hydrothermal fluid. Sediments with relatively higher geothermal gradients mature earlier (low oil window) than those with low gradient values (Nwankwo and Ekine, 2010.), therefore, high geothermal gradient enhances the early formation of oil at relatively shallow burial depths, but it causes the depth range of the oil window to be quite narrow, while low geothermal gradient causes the first formation of oil to begin at fairly deep subsurface levels, but makes the oil window to be quite broad (Anakwuba and Chinwuko, 2015), with this in mind, the Niger Delta Basin around Ozuzu, Omoecheigbo, Etche, Okoroagu, Owaza, Ikono, NkuotEtok, Arochukwu, Isiala, Kala Abak, Ikot Ekpene, Osisioma, Omumma, Obite, Umuede and OkeIkpe interpreted to have low thermal gradient is interpreted to have fairly deep first oil formation levels but quite broad oil window, while Anambra Afikpo Basin observed around Aka Ihobe, Achina, Abarigwe, Ezzamgbo, Isieke, Ishielu, Enugu, Ezeagu, Udi, Ozalla, AmagoEbenebe, Akwa, Orumba, Uturu, Otamkpa, Ahaba, Uzuakoli, Bende, Owerri, Afikpo and Ohafia recording high geothermal gradient is interpreted to have early formation of oil at shallow burial depth but quite narrow oil window.

Sediment cover at the eastern and southeastern part of the study area is generally low and may not support hydrocarbon formation, while other parts of the study area have sediment thickness that is moderate to high. Wright et al (1985) showed that the minimum thickness of sediment required to achieve the threshold temperature of $115^{\circ} \mathrm{C}$ for the commencement of oil formation from organic remains would be $2.3 \mathrm{~km}$ deep when all other conditions for hydrocarbon accumulation are favourable and the average temperature gradient of $1^{\circ} \mathrm{C}$ for 30 $\mathrm{m}$ obtainable in oil rich Niger Delta is applicable. In line with this, for any area to be viable for hydrocarbon formation, the thickness of the sediment must be up to $2.0 \mathrm{~km}$ as well as other conditions necessary for hydrocarbon formations (Wright et al, 1985). The potential of hydrocarbon generation and accumulation is feasible around Ozuzu, Omoecheigbo, Etche, Okoroagu, Owaza, Ikono, NkuotEtok, Arochukwu, Isiala, Kala Abak, Ikot Ekpene, Osisioma, Omumma, Obite, Umuede, OkeIkpe, Aka Ihobe, Achina, Abarigwe, Ezzamgbo, Isieke, Ishielu, Enugu, Ezeagu, Udi, Ozalla, Amago Ebenebe, Akwa, Orumba, Uturu, Otamkpa, Ahaba, Uzuakoli, Bende and Afikpo.

\section{CONCLUSION}

Airborne magnetic dataset covering southeastern Nigeria was acquired, processed and filtered for the interpretation of structures and sedimentary thickness within the study area. The structural interpretation revealed that structures trend majorly in the NE SE direction, with minor NW SE and NS trends. The Southern Benue Trough, Anambra and Afikpo Basin and Niger Delta Basin is dominated by NE SW trending structure while the Southeastern Basement Complex, observed 
around Ugep, Obubra, Adu, Agoibani, Barase, Iko Ekperem, and Esuk Akpai host structures trending NW SE with minor NE SW and EW structures.

Sediment thickness was evaluated using the Extended Euler Depth solution. Sediment thickness within the southern Benue Trough ranges from 151.1 to $1297.4 \mathrm{~m}$. Afikpo Basin has sediment thickness ranging from 513.9 to $>3469.6 \mathrm{~m}$, while Anambra Basin has sediment thickness ranging from 228.4 to $>3469.6 \mathrm{~m}$. the thickest sedimentary unit within the Afikpo Basin is geographically located around Bende, Iduma, Ohafia, Okigwe, Abiriba, Uzuakolo and Amaeke, while that of the Anambra Basin is geographically located around Aka Ihobe, Orumba, Owere Ezukala, Mbala, Agwu, Isuochi, Akwa, Umuawulu, Ezeagu, Onuba, Agbani and Abawa Ogugu. Niger Delta Basin has the high sediment thickness with range of 3469.6 to $6760 \mathrm{~m}$, with the thickest sediment geographically located around Omodema, Abara, Omoecheigbo, Etche, Imogwa, Okoroagu.

\section{REFERENCES}

[1] Appiah, D. (2015). Aeromagnetic and Airborne Radiometric data interpretation on chirano Area of the sefwi Gold Belt. Unpubl. Thesis $112 \mathrm{p}$.

[2] Mariita, N.O, (2013). Application of potential field methods for Geothermal Exploration-A case for Olkaria and menengai Geothermal Field, Kenya Presented at short course viii on Exploration for Geothermal Resources, Organized by UNU-GTP, GDC and KenGen, at Lake Bogoria and Lake Naivasha, Kenya.13p.

[3] Murat, R.C.(1972). Stratigraphy and Paleogeography of the Cretaceous and Lower Tertiary inSouthern Nig. African Geol. Ibadan, Pp251-268.
[4] Mushayandebvu, M. F., van Driel, P., Reid, A. B., \& Fairhead, J. D.,2001, Magnetic source parameters of two-dimensional structures us-ing extended Euler deconvolution: Geophysics, 66, 814-823.

[5] Murphy, B. S. (2007). Airborne Geophysics and the Indian Scenario. Indian Geophysics Union Journal 11(1), 1-28

[6] Ndougsa - Mbarga, T., Feumoe, A.N.S., Manguelle- Dicoum, E., \& fairhead, J.D. 2012. Aeromagnetic Data interpretation to locate Buried faults in South-East Cameroom. Geophysics, 48(1-2), 4963

[7] Nwachukwu, S.O., (1972). The Tectonic Evolution of the Southern Portion of the Benue Trough,Nigeria. Geol. Mag;109(30): 411419.

[8] Odigi, M.I. (2012). Sedimentology of the Nkporo Campanian Maastrichtian conglomeratic Formation, Afikpo Sub-basin, southeastern Benue Trough, Nigeria. J. Min. Geol. 48. 45-55.

[9] Odigi, M, I. \& Amajor, L. C.(2009). Brittle deformation of the Afikpo Basin, SE Nigeria: Evidence for a terminal Cretaceous extensional regime in the Lower Benue Trough; Chin. J. Geochem. 28(4) 369-376.

[10] Ojoh, K. A. (1992). The Southern part of the Benue Trough (Nigeria) Cretaceous stratigraphy, basin analysis, paleooceanography and geodynamic evolution in the equatorial domain of the South Atlantic. NAPE Bull 7:131-152.

[11] Olade, M. A.(1975). Evolution of Nigeria's Benue Trough (Aulacogen): A tectonic model; Geol. Mag. 112 575-581.

[12] Reid, Ab. B., Allsop, J.M., Granser, H., Millett, A.J., \& IW Somerton (1990) Geophysics 55 (1), 80-91,

[13] Salem, A., Ushijima, K., Elsirafi, A., and Mizunaga, A. (2000). Spectral Analysis of Aeromagnetic data for Geothermal Reconnaissance of Quseir Area. North Red Sea, Egypt. Proceeding World Geothermal congress Japan 6p.

[14] Telford, W. M., Geldart, L. P., Sheriff, R.E.(1990). Applied Geophysics, Cambridge University Press. second edition. 